[Article]

\title{
$\mathrm{FC}(\mathrm{O}) \mathrm{SNCO}$ 的电子结构和光电离解离过程
}

\author{
赵春红 ${ }^{1,2}$ 佟胜睿 ${ }^{1, *}$ 葛茂发 ${ }^{1}$ 孙 政 ${ }^{2, *}$ \\ ( ${ }^{1}$ 中国科学院化学研究所, 分子动态与稳态结构国家重点实验室, 北京分子科学国家实验室, 北京 100190 ; \\ 2 河北师范大学化学与材料科学学院, 石家庄 050024)
}

\begin{abstract}
摘要: 由于拥有 $-\mathrm{C}(\mathrm{O}) \mathrm{S}$ - 和 $-\mathrm{NCO}$ 基团, $\mathrm{FC}(\mathrm{O}) \mathrm{SNCO}$ 的分子和电子结构是非常有趣的. 利用 $\mathrm{FC}(\mathrm{O}) \mathrm{SCl}$ 和 $\mathrm{AgNCO}$ 制备了 $\mathrm{FC}(\mathrm{O}) \mathrm{SNCO}$, 并利用 $\mathrm{Hel}$ 光电子能谱(PES)、光电离质谱(PIMS)以及理论计算研究了其分子和 电子结构. 通过将实验、理论计算以及自然键轨道(NBO)分析结合起来, 获得了 FC $(\mathrm{O}) \mathrm{SNCO}$ 的最稳定分子构 型. 利用外壳层格林函数(OVGF)方法以及与相似化合物的比较, 对其光电子能谱进行了指认. 理论计算表明, 对于中性分子最稳定的构型为 syn-syn 非平面构型, 而电离后的离子最稳定构型为 syn-syn 平面构型. 实验结 果表明, 第一电离能来自于 $S$ 的孤对电子轨道, 为 $10.33 \mathrm{eV}$. 第二至第六电离能分别为 $12.03 、 13.23 、 13.77$ 、 14.78、15.99 eV, 并对这些电离能进行了指认. 在光电离质谱中产生了六个质谱峰, 分别为 $\mathrm{SN}^{+} 、 F C(O)^{+} 、$ $\mathrm{SNCO}^{+} 、 \mathrm{FC}(\mathrm{O}) \mathrm{SN}^{+} 、 \mathrm{C}(\mathrm{O}) \mathrm{SNCO}^{+} 、 \mathrm{FC}(\mathrm{O}) \mathrm{SNCO}^{+}$, 其中 $\mathrm{FC}(\mathrm{O}) \mathrm{SNCO}^{+}$的峰是最强峰. 结合 $\mathrm{Hel}$ 光电子能谱和 理论计算, 对 PIMS 进行了分析, 并研究了可能的电离和解离过程并对其进行了讨论.
\end{abstract}

关键词: 结构; Hel光电子能谱; 光电离质谱; 理论计算; 电离和解离过程 中图分类号: 0641

\section{Electronic Structure and Photoionization Dissociation Process of $\mathrm{FC}(\mathrm{O}) \mathrm{SNCO}$}

\author{
ZHAO Chun-Hong ${ }^{1,2} \quad$ TONG Sheng-Rui ${ }^{1, *} \quad$ GE Mao-Fa ${ }^{1} \quad$ SUN Zheng ${ }^{2, *}$ \\ ('Beijing National Laboratory for Molecular Sciences, State Key Laboratory for Structural Chemistry of Unstable and \\ Stable Species, Institute of Chemistry, Chinese Academy of Sciences, Beijing 100190, P. R. China; \\ ${ }^{2}$ College of Chemistry and Materials Sciences, Hebei Normal University, Shijiazhuang 050024, P. R. China)
}

\begin{abstract}
Fluorocarbonyl) sulfenyl isocyanate (FC(O)SNCO) contains $-\mathrm{C}(\mathrm{O}) \mathrm{S}-$ and $-\mathrm{NCO}$ groups, so has an interesting electronic and molecular structure. $\mathrm{FC}(\mathrm{O}) \mathrm{SNCO}$ was prepared by the metathesis of $\mathrm{FC}(\mathrm{O}) \mathrm{SCl}$ and AgNCO. Hel photoelectron spectroscopy (PES), photoionization mass spectrometry (PIMS), and theoretical calculations were used to study the molecular and electronic structure of $\mathrm{FC}(\mathrm{O}) \mathrm{SNCO}$. The experimental, theoretical calculations, and NBO results indicated the most stable conformer of $F C(O) S N C O$. In addition to the outer-valence Green's function calculation, the PES spectrum was assigned from analogous studies of similar molecules. The syn-syn non-planar conformer $\left(\delta_{\mathrm{FCSN}}=180^{\circ}\right)$ with $C_{1}$ symmetry was favored by the neutral molecule, and changed to the syn-syn planar structure with $C_{s}$ symmetry after ionization. The experimental first vertical ionization potential mainly from the $\mathrm{S}$ lone pair orbital was $10.33 \mathrm{eV}$. The second to sixth ionization potentials of $\mathrm{FC}(\mathrm{O}) \mathrm{SNCO}$ were 12.44, 13.23, 13.77, 14.78, and $15.99 \mathrm{eV}$, respectively, and were also assigned. The $\mathrm{FC}(\mathrm{O})^{+}, \mathrm{SN}^{+}, \mathrm{FC}(\mathrm{O}) \mathrm{SN}^{+}, \mathrm{SNCO}^{+}, \mathrm{C}(\mathrm{O}) \mathrm{SNCO}^{+}$, and $\mathrm{FC}(\mathrm{O}) \mathrm{SNCO}^{+}$peaks were observed in the PIMS spectrum, the highest intensity of which was $\mathrm{FC}(\mathrm{O}) \mathrm{SNCO}^{+}$. The PIMS data were analyzed based
\end{abstract}

Received: September 3, 2014; Revised: October 30, 2014; Published on Web: October 31, 2014.

"Corresponding authors. TONG Sheng-Rui, Email: tongsr@iccas.ac.cn; Tel: +86-10-62558682. SUN Zheng, Email: sunzheng@hebtu.edu.cn; Tel: +86-311-86268143.

The project was supported by the Strategic Priority Research Program (B) of the Chinese Academy of Sciences (XDB05010400), National Natural Science Foundation of China (41105085, 21073051), and Natural Science Foundation of Hebei Province, China (B2010000368) 中国科学院战略性先导专项 B (XDB05010400), 国家自然科学基金(41105085, 21073051)及河北省自然科学基金(B2010000368)资助项目

(C) Editorial office of Acta Physico-Chimica Sinica 
on the PES and theoretical results. Possible ionization and dissociation processes are discussed.

Key Words: Structure; Hel photoelectron spectroscopy; Photoionization mass spectroscopy; Theoretical calculation; Ionization and dissociation processes

\section{Introduction}

A wide series of studies on thiol ester compounds have been carried out because of their close relation to many biomolecules. For instance, acetyl CoA, is well known as a biological acetylating reagent, leading to a reductive scission of the $\mathrm{S}-\mathrm{S}$ linkage of 6,8-thioctic acid to form a dithiol. ${ }^{1}$ It is also of great importance in biochemistry as a condensing agent. Due to the important role against free radicals, the S-acyl-CoA and reduced glutathione GSH are also seen as important intermediates in the metabolism of acidic drugs. Some thiol esters also represent as latent medicine which can be reactivated through hydrolysis. ${ }^{2}$ Needless to say, at present it is difficult to explain all the biological activity distinctly. Some significant aspects of them, however, may be examined by the investigation of simple model compounds, such as sulfenyl carbonyl compounds, $\mathrm{XC}(\mathrm{O}) \mathrm{SY}(\mathrm{X}, \mathrm{Y}$ : halogen). $\mathrm{XC}(\mathrm{O}) \mathrm{SY}$ compounds containing $-\mathrm{C}(\mathrm{O}) \mathrm{S}-$ are an interesting family of many theoretical and experimental investigations. Haas and Reinke $^{3}$ reported the preparation of the first such compound in 1966, namely ClC(O)SCl. Since then, several other members of this type of compounds have been characterized, e.g., $\mathrm{FC}(\mathrm{O}) \mathrm{SCl}^{4-7}$ $\mathrm{FC}(\mathrm{O}) \mathrm{SBr}^{8-10}$ and $\mathrm{ClC}(\mathrm{O}) \mathrm{SBr} .{ }^{10,11}$ Recently, the $\mathrm{X}, \mathrm{Y}$ in $\mathrm{XC}(\mathrm{O}) \mathrm{SY}$ represent not only halogen but also pseudohalogen and other substituent groups, e.g., $\mathrm{FC}(\mathrm{O}) \mathrm{SSCN},{ }^{12} \mathrm{CH}_{3} \mathrm{OC}(\mathrm{O}) \mathrm{SNCO},{ }^{13}$ $\mathrm{FC}(\mathrm{O}) \mathrm{SOC}(\mathrm{O}) \mathrm{CH}_{3}{ }^{14}$ and so on. The essentially planar nature of the $\mathrm{XC}(\mathrm{O}) \mathrm{SY}$ skeleton gives rise to syn and anti conformational options. Gas electron diffraction, ${ }^{4}$ vibrational analysis, ${ }^{5}$ and calculations ${ }^{6}$ demonstrated that $\mathrm{FC}(\mathrm{O}) \mathrm{SCl}$ exists as a mixture of two planar forms with the energy of anti conformation $(\mathrm{C}=\mathrm{O}$ bond anti with respect to the $\mathrm{S}-\mathrm{Cl}$ bond) being higher than that of the syn conformer. In all the reported cases, the syn conformation represents the most stable structure. ${ }^{8,10,15}$

Isocyanates as one of the pseudohalide derivatives are important precursors in the synthesis of polymer materials. ${ }^{16}$ The production is based on a nucleophilic addition reaction which takes place via the nucleophile's attack on the carbon of the NCO group. The synthetic procedure gives high yields and exhibits no side reactions. Pseudohalides are examples of distorted linear triatomic systems. It was difficult to predict the conformational stability of simple isocyanates and may also be different in different aggregation states. Several studies have been carried out on the conformational and spectroscopic properties of organoisocyanate molecules. For example, in methoxycarbonylsulfenyl isocyanate, $\mathrm{CH}_{3} \mathrm{OC}(\mathrm{O}) \mathrm{SNCO},{ }^{13}$ the $\mathrm{C}=\mathrm{O}$ double bond synperiplanar with respect to the $\mathrm{S}-\mathrm{N}$ single bond was the most stable form, which confirmed by Fourier transform infrared (FTIR) spectroscopy, ultraviolet visible (UV-Vis) spectroscopy, Xray diffraction (XRD), Raman spectroscopy, and theoretical calculations. Gas-phase electron diffraction (GED), microwave, calculations, and vibrational analysis were used to study the conformational and structural properties of acetylisocyanate $\mathrm{CH}_{3} \mathrm{C}(\mathrm{O}) \mathrm{NCO},{ }^{17}$ all results predicted that in the gas phase and ambient temperature the cis conformer (isocyanate group cis to the carbonyl bond) was more stable than the trans conformer. The studies on conformational properties of $\mathrm{CCl}_{3} \mathrm{C}(\mathrm{O}) \mathrm{NCO}$ were close to those of $\mathrm{CH}_{3} \mathrm{C}(\mathrm{O}) \mathrm{NCO} .^{18}$ In the liquid phases the cis conformer was more stable than the trans conformer indicated by Raman and IR studies, while only the cis conformer was present for $\mathrm{CF}_{3} \mathrm{C}(\mathrm{O}) \mathrm{NCO}$ in the solid phase. ${ }^{19}$

(Fluorocarbonyl) sulfenyl isocyanate, $\mathrm{FC}(\mathrm{O}) \mathrm{SNCO}$, is a very meaningful molecule, which is one of the examples of the $\mathrm{XC}(\mathrm{O}) \mathrm{SY}$ compounds including isocyanate (NCO) group. The conformation of the gaseous $\mathrm{FC}(\mathrm{O}) \mathrm{SNCO}$ has been studied by GED, FTIR, and quantum chemical calculation. ${ }^{20}$ In addition, the vibrational analysis and matrix-photochemical study have been reported. ${ }^{21}$ However, the electronic structure of $\mathrm{FC}(\mathrm{O}) \mathrm{SNCO}$ has never been studied. Our group has a long-term concern with the generation and electronic structures of unstable molecules. ${ }^{22,23}$ The HeI photoelectron spectroscopy (PES), together with theoretical calculation will play an important role in studying electronic structures of compounds. Comparing with the structure investigations, the electronic structures of these unstable molecules can be studied. In this work, the HeI photoelectron spectrum and photoionization mass spectrum (PIMS) of FC(O)SNCO were first reported. The electronic structure of the compound was analyzed based on the HeI photoelectron spectrum in combining with theoretical calculation and photoionization mass spectroscopy.

\section{Experimental}

\subsection{Sample preparation}

In the preparation of isocyanates, silver isocyanate (AgOCN, Alfa, $>97 \%$ ) was found to be a perfect precursor. ${ }^{24}$ In this work, $\mathrm{FC}(\mathrm{O}) \mathrm{SNCO}$ was prepared by substitution reaction of $\mathrm{FC}(\mathrm{O}) \mathrm{SCl}$ and $\mathrm{AgOCN}$ at $-80{ }^{\circ} \mathrm{C}$ for $12 \mathrm{~h}$ according to literature. ${ }^{25}$ The reaction route was illustrated as below:

$\mathrm{FC}(\mathrm{O}) \mathrm{SCl}(\mathrm{g})+\operatorname{AgOCN}(\mathrm{s}) \rightarrow \mathrm{FC}(\mathrm{O}) \mathrm{SNCO}(\mathrm{g})+\mathrm{AgCl}(\mathrm{s})$

The reactant $\mathrm{FC}(\mathrm{O}) \mathrm{SCl}$ was prepared by $\mathrm{ClC}(\mathrm{O}) \mathrm{SCl}(97 \%$, Alfa Aesar) and $\mathrm{TlF}$ (99\%, Acrod, USA) referring to the previous report, ${ }^{26}$ and its potential energy (PE) and IR spectra were identical to the reports previously. ${ }^{27} \mathrm{AgOCN}$ was all purchased from Alfa Aesar Company. Before reaction, AgOCN was dried for $2 \mathrm{~h}$ in vacuum $\left(1.33 \times 10^{-6} \mathrm{~Pa}\right)$. The IR spectrum of gaseous $\mathrm{FC}(\mathrm{O}) \mathrm{SNCO}$ was also obtained. Compared with the reported IR spectroscopy, it was verified that the synthetic compound was $\mathrm{FC}(\mathrm{O}) \mathrm{SNCO}{ }^{21}$

\subsection{Instruments}


A double-chamber UPS-II instrument was used to record the photoelectron spectrum as reported before. ${ }^{28,29}$ The instrument was specially designed to detect unstable species. A little of Ar gas and $\mathrm{CH}_{3} \mathrm{I}$ were acceded to the sample flow tube to calibrate the experimental vertical ionization potentials during the experiments. The spectral resolution of HeI spectrum was about $30 \mathrm{meV}$. The mass spectrum was recorded by a time-of-flight mass spectrometer and mounted directly to the double-chamber UPS-II instrument. The soft ionization was supplied by single wavelength HeI radiation. The instrument was represented in detail in the previous paper. ${ }^{29}$ Under identical conditions the photoelectron and photoionization mass spectra can be recorded within seconds of each other.

\subsection{Theoretical computation}

The geometry of the neutral ground state was optimized using MP2/6-311 + $\mathrm{G}(d, p)$ and B3LYP/6-311++ G $(d, p)$. Harmonic vibrational frequencies were also calculated to check whether the optimized structure was a stationary point or a saddle point. The potential functions for internal rotation around the $\mathrm{C}-\mathrm{S}$ were performed to search for other possible formers of $\mathrm{FC}(\mathrm{O}) \mathrm{SNCO}$ at the MP2/6-311++ $\mathrm{G}(d, p), \mathrm{B} 3 \mathrm{LYP} / 6-311++\mathrm{G}(d, p)$, and HF/6-311++ $\mathrm{G}(d, p)$ levels. At the B3LYP/6-311++G(3df,3pd) level, the natural bond orbital (NBO) calculations were calculated. To assign the photoelectron spectrum, the out-valence Green's function (OVGF) calculation, which included sophisticated correlation effects of the self-energy, was applied to the most stable conformers of $\mathrm{FC}(\mathrm{O}) \mathrm{SNCO}$ to give accurate results of the vertical ionization energies. Gaussian 03 program was used for calculations. ${ }^{30}$ Threedimensional molecular orbital (MO) plots were obtained with the Gauss View program, and each orbital displayed with the 0.06 isodensity value was oriented in a way that allowed for the best view. The Mulliken population analysis was applied to assign the charges for both neutral and cationic-radical forms.

\section{Results and discussion}

\subsection{Molecular structure}

In order to seek other possible conformers of $\mathrm{FC}(\mathrm{O}) \mathrm{SNCO}$, the potential functions for internal rotation around the $\mathrm{C}-\mathrm{S}$ were performed by rotating the torsional dihedral angle $\left(\delta_{\mathrm{FCSN}}\right)$ in steps of $10^{\circ}$ ranging from $0^{\circ}$ to $360^{\circ}$ at the MP2/6-311++ $\mathrm{G}(d, p)$, B3LYP/6-311++G( $d, p)$, and HF/6-311++G $(d, p)$ levels (Fig.1). All these methods predicted that the syn-syn structure $\left(\delta_{\mathrm{FCSN}}=180^{\circ}\right)$ was the global minimum form. At the same time, a second minimum was anti-anti structure $\left(\delta_{\mathrm{FCSN}}=0^{\circ}\right)$. The structural optimization and vibrational analysis indicated that the syn-syn and antianti conformers of $\mathrm{FC}(\mathrm{O}) \mathrm{SNCO}$ were stable, which were shown in Fig.2. Relative Gibbs free energies $(\Delta G)$ for the two stable conformers of $\mathrm{FC}(\mathrm{O}) \mathrm{SNCO}$ at $298 \mathrm{~K}$ after optimization were calculated. The second stable form was anti-anti former with the energy gaps of $8.00,7.29$, and $10.84 \mathrm{~kJ} \cdot \mathrm{mol}^{-1}$ based at the $\mathrm{HF} / 6$ $311++\mathrm{G}(d, p), \mathrm{B} 3 \mathrm{LYP} / 6-311++\mathrm{G}(d, p)$, and MP2/6-311++G $(d, p)$ levels, respectively. All the computational methods predicted that the syn-syn conformer was the most stable. This can be explained by the sulfur lone-pair and steric interactions between $\mathrm{FC}(\mathrm{O})$ and

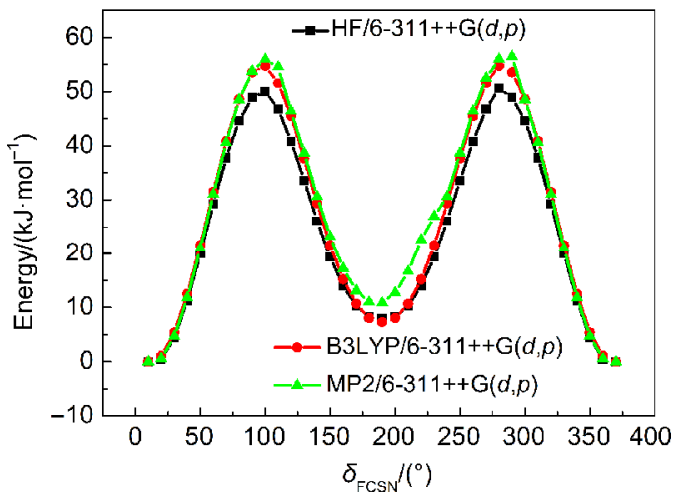

Fig.1 Relative energies of $\mathrm{FC}(\mathrm{O}) \mathrm{SNCO}$ with different dihedral angles $\left(\delta_{\mathrm{FCSN}}\right)$ calculated at the HF/6-311++G $(d, p), \mathrm{B} 3 \mathrm{LYP} / 6-311++$ $\mathrm{G}(d, p)$, and MP2/6-311++G(d,p) levels
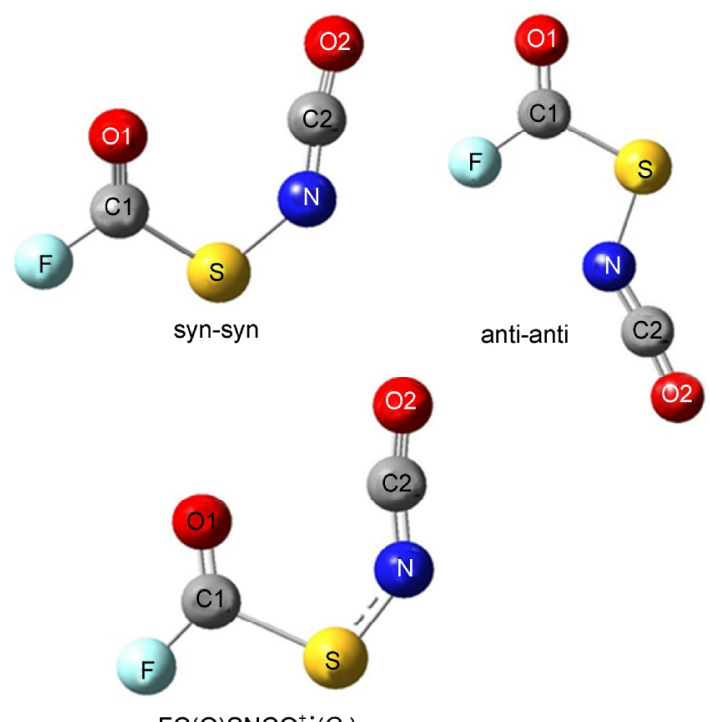

$\mathrm{FC}(\mathrm{O}) \mathrm{SNCO}^{+*}\left(C_{s}\right)$

Fig.2 Schematic representation of FC(O)SNCO

NCO groups.

Probably the most interesting and contrasting results uncovered by the potential energy curves shown in Fig.1 are the very different rotational barriers obtained for the two studied compounds. Computed energy barriers $E_{\text {a }}$ for the syn $\rightarrow$ anti internal rotation were derived from fully optimized transition state (TS) structures at B3LYP levels of theory. The TS (Fig.3) structures were verified by an intrinsic reaction coordinate calculation to connect the conformers along the reaction path for the normal coordinate of the imaginary frequency.

To gain some deep information on the stabilities of syn-syn and anti-anti conformations of $\mathrm{FC}(\mathrm{O}) \mathrm{SNCO}$, NBO calculations were also performed on these two conformers. The most important orbital interactions occur between the two sulfur lone pairs relevant to the conformational properties, $\operatorname{lp}_{\pi} \mathrm{S}(2)$ and $\operatorname{lp}_{\sigma} \mathrm{S}(1)[\mathrm{lp}$ : lone pair; the $\operatorname{lp}_{\sigma} \mathrm{S}(1)$ orbital is parallel to the $\sigma^{*}(\mathrm{C} 1-\mathrm{O} 1)$ bond, the $\operatorname{lp}_{\pi} \mathrm{S}(2)$ orbital is parallel to the $\pi(\mathrm{Cl}=\mathrm{O} 1)$ bond]. The occupancies of $\operatorname{lp}_{\sigma} \mathrm{S}(1)$ and $\operatorname{lp}_{\pi} \mathrm{S}(2)$ are $1.98 e$ and $1.79 e$, respectively. The lower occupancy of $\mathrm{lp}_{\pi} \mathrm{S}(2)$ indicates its strong electron-donor capacity. The strongest interactions are due to donations from $\operatorname{lp}_{\pi} \mathrm{S}(2)$ to the 


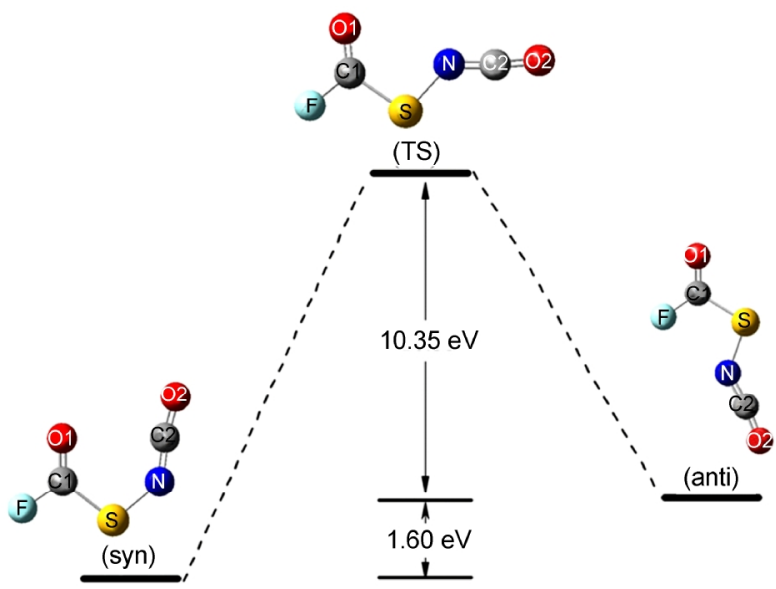

Fig.3 Optimized structures, labeling of the atoms, and relative energies of the syn, anti conformations, and rotational transition state (TS) of FC(O)SNCO molecule at the B3LYP/6-311++G $(d, p)$ level

unoccupied molecular orbits $\pi^{*}(\mathrm{C} 1=\mathrm{O} 1)\left[\mathrm{lp}_{\pi} \mathrm{S}(2) \rightarrow \pi^{*}(\mathrm{C} 1=\mathrm{O} 1)\right]$ and $\pi^{*}(\mathrm{~N}=\mathrm{C} 2)\left[\mathrm{lp}_{\pi} \mathrm{S}(2) \rightarrow \pi^{*}(\mathrm{~N}=\mathrm{C} 2)\right]$. This is evidenced by high occupancy of the two antibonding orbitals $\pi^{*}(\mathrm{C} 1=\mathrm{O} 1)(0.27 e)$, anti-anti form, which contributes to stabilization of an approximate planar structure for $\mathrm{FC}(\mathrm{O}) \mathrm{SNCO}$ by resonance (mesomeric effect). As shown in Table 1, these interactions contribute similarly to stabilization energies for both the syn-syn and anti-anti forms. However, delocalization of $\operatorname{lp}_{\sigma} \mathrm{S}$ reveals a strong conformational dependence. In account with the anomeric effect, the $\operatorname{lp}_{\sigma} \mathrm{S}(1) \rightarrow \sigma^{*}(\mathrm{C} 1-\mathrm{O} 1)$ interaction stabilized the syn-syn form by $21.87 \mathrm{~kJ} \cdot \mathrm{mol}^{-1}$, while the corresponding delocalization in the antianti form is below the threshold for printing $\left(2.09 \mathrm{~kJ} \cdot \mathrm{mol}^{-1}\right)$. On the other hand, the syn-syn form is favored through $\operatorname{lp}_{\sigma} \mathrm{S}(1) \rightarrow$ $\sigma^{*}(\mathrm{C} 1-\mathrm{F})$ delocalization by $11.77 \mathrm{~kJ} \cdot \mathrm{mol}^{-1}$. Thus, considering the electronic contributions of both lone pairs at the sulfur atom, the syn-syn form is favored by $22.73 \mathrm{~kJ} \cdot \mathrm{mol}^{-1}$. Similar results were reported also for other sulfenylcarbonyl molecules. ${ }^{31}$

In the previous work, the conformational properties of $\mathrm{FC}(\mathrm{O}) \mathrm{SNCO}$ have been investigated by gas electron diffraction, ${ }^{20}$ theoretical calculation, and matrix infrared spectra. ${ }^{21}$ Only a synsyn conformation (carbonyl $\mathrm{C}=\mathrm{O}$ syn with $\mathrm{S}-\mathrm{N}$ and the $\mathrm{NCO}$

Table 1 NBO stabilization energies for orbital interactions associated with sulfur lone pair (lp) in $\mathrm{FC}(\mathrm{O}) \mathrm{SNCO}$ calculated at the B3LYP/6-311++G(3df,3pd $)$ level

\begin{tabular}{|c|c|c|}
\hline \multirow{2}{*}{ Item } & \multicolumn{2}{|c|}{ Value } \\
\hline & syn-syn & anti-anti \\
\hline $\mathrm{lp}_{\sigma} \mathrm{S}(1) \rightarrow \sigma^{\circ}(\mathrm{C} 1-\mathrm{F})$ & & 11.77 \\
\hline $\operatorname{lp}_{\sigma} \mathrm{S}(1) \rightarrow \sigma^{\circ}(\mathrm{C} 1=\mathrm{O} 1)$ & 18.80 & \\
\hline $\mathrm{lp}_{\pi} \mathrm{S}(2) \rightarrow \pi^{*}(\mathrm{C} 1=\mathrm{O} 1)$ & 138.84 & 125.61 \\
\hline $\operatorname{lp}_{\pi} \mathrm{S}(2) \rightarrow \pi^{*}(\mathrm{~N}=\mathrm{C} 2)$ & 52.21 & 49.74 \\
\hline$\Delta E_{\text {anom }} /\left(\mathrm{kJ} \cdot \mathrm{mol}^{-1}\right)$ & \multicolumn{2}{|c|}{7.03} \\
\hline$\Delta E_{\text {conj }} /\left(\mathrm{kJ} \cdot \mathrm{mol}^{-1}\right)$ & \multicolumn{2}{|c|}{15.70} \\
\hline$\Delta E_{\text {total }} /\left(\mathrm{kJ} \cdot \mathrm{mol}^{-1}\right)$ & \multicolumn{2}{|c|}{22.73} \\
\hline
\end{tabular}

$\Delta E$ : syn-syn and anti-anti energy difference. Note that positive value contributes to stabilization of the syn-syn rotamer. $\Delta E_{\text {anom: }}$ anomeric interaction energy difference. $\Delta E_{\text {conj }}$ : conjugation interaction energy difference. $\Delta E_{\text {total }}=\Delta E_{\text {anom }}+\Delta E_{\text {conj }}$ group syn to $\mathrm{C}-\mathrm{S}$ ) was confirmed to be the most stable conformer at ambient temperature. The result of our theoretical calculation agreed with the previous studies. Therefore, our calculations were all based on the syn-syn conformer.

Most of the series of compound used B3LYP method, such as $\mathrm{CH}_{2}=\mathrm{CHC}(\mathrm{O}) \mathrm{NCO},{ }^{32} \mathrm{FC}(\mathrm{O}) \mathrm{SOC}(\mathrm{O}) \mathrm{CH}_{3},{ }^{14} \mathrm{CH}_{3} \mathrm{OC}(\mathrm{O}) \mathrm{SCH}_{3},{ }^{13}$ FCOSSCN, ${ }^{12} \mathrm{FC}(\mathrm{O}) \mathrm{SCN},{ }^{31}$ and so on. For neutral and cationic $\mathrm{FC}(\mathrm{O}) \mathrm{SNCO}$, full geometry optimizations and frequency calculations were performed on the syn-syn conformer at the B3LYP/ $6-311++\mathrm{G}(d, p)$ basis set. Table 2 compared experimental and calculation geometric parameter of $\mathrm{FC}(\mathrm{O}) \mathrm{SNCO}$. The structure obtained by theoretical calculations was in accordance with the GED results. ${ }^{20}$ Fig. 2 showed the geometric parameters of the ground cationic-radical form $\mathrm{FC}(\mathrm{O}) \mathrm{SNCO}^{+}{ }^{\bullet}$, which were also calculated by the B3LYP approach at the same basis set. After the vibrational analysis, the most stable conformer of the cationicradical form was $C_{s}$ symmetry (Fig.2).

\subsection{Photoelectron spectroscopy}

In combination with theoretical calculations, PES with HeI resonance source $(58.4 \mathrm{~nm})$ is an effective method to investigate the electronic structure of unstable compounds and free radicals. ${ }^{33}$ By HeI photoelectron energy analysis, the valence shell structure of the molecule can be obtained, especially for investigating similar molecules. ${ }^{34}$ The HeI photoelectron spectroscopy spectrum of FC(O)SNCO is presented in Fig.4. Table 3 listed the experimental ionization potentials (IP in eV) and theoretical vertical ionization energies $\left(E_{\mathrm{v}}\right.$ in $\left.\mathrm{eV}\right)$ as well as corresponding characters of each occupied molecular orbital. The OVGF pole strengths in Table 4 are all larger than 0.85 , which agrees with a one-electron depiction of ionization. If the OVGF pole strengths are smaller than 0.85 , OVGF approach would be unapplicable because a severe breakdown of the orbital (or one-electron) picture of ionization should be expected..$^{35}$ To obtain the ionization energies for $\mathrm{FC}(\mathrm{O}) \mathrm{SNCO}$, OVGF calculations were carried out before assigning the spectrum. All the calculations were based on the

Table 2 Experimental and calculated geometric parameters for syn-syn conformer of $\mathrm{FC}(\mathrm{O}) \mathrm{SNCO}^{\mathrm{a}}$

\begin{tabular}{|c|c|c|c|}
\hline \multirow{3}{*}{ Parameter } & \multicolumn{3}{|c|}{ Value } \\
\hline & \multicolumn{2}{|c|}{ neutral } & cation \\
\hline & $\mathrm{GED}^{\mathrm{b}}$ & B3LYP & B3LYP \\
\hline$r_{\mathrm{Cl}-\mathrm{s}} / \mathrm{nm}$ & $0.1748(5)$ & 0.1775 & 0.1907 \\
\hline$r_{\mathrm{Cl}-\mathrm{Ol} /} / \mathrm{nm}$ & $0.1187(5)$ & 0.1181 & 0.1168 \\
\hline$r_{\mathrm{Cl}-\mathrm{F}} / \mathrm{nm}$ & $0.1333(4)$ & 0.1353 & 0.1298 \\
\hline$r_{\mathrm{s}-\mathrm{N}} / \mathrm{nm}$ & $0.1669(3)$ & 0.1681 & 0.1598 \\
\hline$r_{\mathrm{N}-\mathrm{C} 2} / \mathrm{nm}$ & $0.1208(8)$ & 01.216 & 01.248 \\
\hline$r_{\mathrm{C} 2-\mathrm{O} 2} / \mathrm{nm}$ & $0.1167(5)$ & 0.1162 & 0.1139 \\
\hline$\alpha_{\mathrm{SClO1} 1} /\left(^{\circ}\right)$ & $129.5(8)$ & 128.8 & 121.8 \\
\hline$\alpha_{\mathrm{SCIF}} /\left(^{\circ}\right)$ & $107.3(5)$ & 107.4 & 107.8 \\
\hline$\alpha_{\mathrm{OICIF}} /\left(^{\circ}\right)$ & $123.2(10)$ & 123.8 & 130.4 \\
\hline$\alpha_{\mathrm{CISN}} /\left(^{\circ}\right)$ & $101.6(20)$ & 101.5 & 100.5 \\
\hline$\alpha_{\mathrm{SNC} 2} /\left(^{\circ}\right)$ & $127.8(14)$ & 136.0 & 139.2 \\
\hline$\alpha_{\mathrm{NC} 202} /\left(^{\circ}\right)$ & $165.9(32)$ & 172.1 & 171.0 \\
\hline$\delta_{\text {OICISN }} /\left(^{\circ}\right)$ & 0.000 & 2.0 & 0.0 \\
\hline$\delta_{\mathrm{ClSNC} 2} /\left(^{\circ}\right)$ & $17(6)$ & -22.3 & 0.0 \\
\hline
\end{tabular}

a atom numbering shown in Fig. $2 ;{ }^{\text {b }}$ taken from Ref. 27 


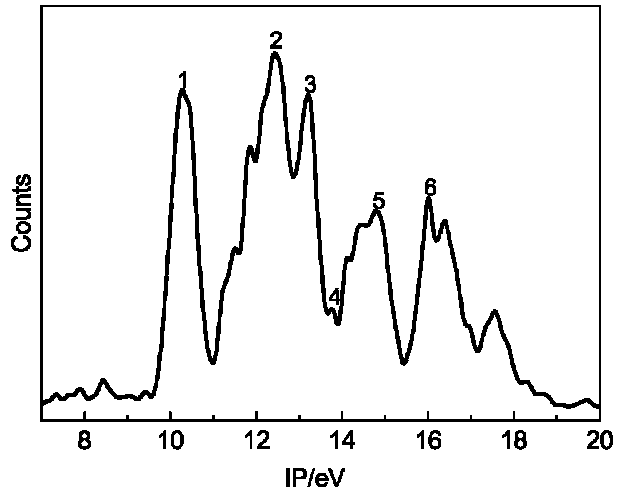

Fig.4 Photoelectron spectroscopy of FC(O)SNCO

Table 3 Experimental vertical ionization potentials $\left({ }^{\left(P^{\text {exp }}\right)}\right.$ ), calculated vertical ionization potentials ${ }^{\mathrm{a}}$ (IP ${ }^{\text {calcd }}$ ) as obtained by OVGF/6-311++G** and MO characters for FC(O)SNCO

\begin{tabular}{cccc}
\hline $\mathrm{IP}^{\text {expr }} / \mathrm{eV}$ & $\mathrm{IP}^{\text {calcd }} / \mathrm{eV}$ & MO & Character $^{\mathrm{b}}$ \\
\hline 10.33 & $10.097(0.91)$ & $30 \mathrm{a}$ & $n_{\mathrm{S}}$ \\
12.44 & $12.197(0.90)$ & $29 \mathrm{a}$ & $n_{\mathrm{o}}, \pi_{\text {NCO }}$ \\
13.23 & $13.259(0.90)$ & $28 \mathrm{a}$ & $n_{\mathrm{o}}, \pi_{\text {sNCO }}$ \\
13.77 & $13.448(0.90)$ & $27 \mathrm{a}$ & $\pi_{\text {sNCo }}$ \\
14.78 & $15.218(0.88)$ & $26 \mathrm{a}$ & $n_{\mathrm{F}}, \pi_{\mathrm{c}-\mathrm{o}}$ \\
15.99 & $15.463(0.89)$ & $25 \mathrm{a}$ & $\sigma, n_{\mathrm{F}}$ \\
\hline
\end{tabular}

a pole strength in parentheses; ${ }^{b}$ molecular orbital corresponding to the assignment of ionization energy

Table 4 Atomic charges for the neutral (syn-syn) and cationicradical (syn-syn) conformer of $\mathrm{FC}(\mathrm{O}) \mathrm{SNCO}$ as obtained by the B3LYP/6-311++G $(d, p)$ level

\begin{tabular}{cccrrrrrr}
\hline & \multicolumn{1}{c}{ Atomic charge $/ e$} & \multicolumn{1}{c}{ TAC $^{\mathrm{b}} / e$} \\
\cline { 2 - 8 } & $\mathrm{C} 1$ & \multicolumn{1}{c}{$\mathrm{S}$} & \multicolumn{1}{c}{$\mathrm{O} 1$} & \multicolumn{1}{c}{$\mathrm{F}$} & \multicolumn{1}{c}{$\mathrm{N}$} & \multicolumn{1}{c}{$\mathrm{C} 2$} & \multicolumn{1}{c}{$\mathrm{O} 2$} & \\
\hline $\mathrm{FC}(\mathrm{O}) \mathrm{SNCO}$ & 0 & 0.34 & -0.18 & -0.07 & -0.26 & 0.38 & -0.21 & 0 \\
$\mathrm{FC}(\mathrm{O}) \mathrm{SNCO}^{+}$ & 0.06 & 0.62 & -0.06 & 0.05 & -0.10 & 0.44 & -0.01 & 1 \\
$\Delta q^{\mathrm{c}}$ & 0.06 & 0.28 & 0.12 & 0.12 & 0.16 & 0.06 & 0.20 & 1 \\
\hline
\end{tabular}
${ }^{a}$ atom numbering, shown in Fig. 2 ; ${ }^{b}$ total atomic charge;

${ }^{\circ} \Delta q=q\left(\mathrm{FC}(\mathrm{O}) \mathrm{SNCO}^{+}\right)-q(\mathrm{FC}(\mathrm{O}) \mathrm{SNCO})$

most stable conformer syn-syn. Fig. 5 shows the characters of the some occupied molecular orbitals of FC(O)SNCO.

It can be clearly seen from Table 3, the ionization energies of different bands are in consistent with the calculated values of OVGF method. Combining with band profiles, relative band intensities, comparison with the similar compounds, and theoretical method (OVGF calculation), the bands in the photoelectron spectra can be reliable assignments. The assignment of the photoelectron spectrum of $\mathrm{FC}(\mathrm{O}) \mathrm{SNCO}$ is obtained easily, because lone pairs generally display no fine structure.

In the photoelectron spectrum, the first ionization band of $\mathrm{FC}(\mathrm{O}) \mathrm{SNCO}$ was at $10.33 \mathrm{eV}$ that can be contributed to the ionization process from the highest occupied molecular orbital (HOMO) $\left[n_{\pi}(\mathrm{S})\right]$, which can be direct-viewing as a lone pair formally localized on the sulfur atom. This is similar to $\mathrm{FC}(\mathrm{O}) \mathrm{SCl}$, its precursor. ${ }^{36}$ The first ionization energy $(10.7 \mathrm{eV})$ of $\mathrm{FC}(\mathrm{O}) \mathrm{SCl}$ also is from the ionization of lone pair of the sulfur atom. For $\mathrm{FC}(\mathrm{O}) \mathrm{SNCO}$ the first vertical ionization energy is slightly lower $(0.37 \mathrm{eV})$ than $\mathrm{FC}(\mathrm{O}) \mathrm{SCl}$ in photoelectron spectrum. The reason was that the highly polar $\mathrm{S}^{+}-\mathrm{O}^{-}$of the $\mathrm{S}-\mathrm{O}$

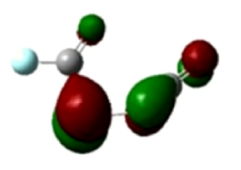

$30 \mathrm{a}$

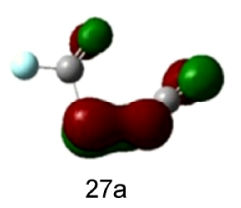

Fig.5 Characters of the occupied molecular orbitals (MOs) for FC(O)SNCO

bond in sulfenic esters RSOR'. Because the electronegativity of $\mathrm{F}$ is larger than that of $\mathrm{CH}_{3} \mathrm{O}$, it results in more electrons on $\mathrm{S}$ lone pair of $\mathrm{FC}(\mathrm{O}) \mathrm{SNCO}$. The first ionization of $\mathrm{FC}(\mathrm{O}) \mathrm{SNCO}$ is higher $(0.77 \mathrm{eV})$ than that of $\mathrm{CH}_{3} \mathrm{OC}(\mathrm{O}) \mathrm{SNCO}(9.56 \mathrm{eV}) .{ }^{13}$ The first band of $\mathrm{ClC}(\mathrm{O}) \mathrm{SCl}^{37}$ is located at $10.36 \mathrm{eV}$, which can be assigned to the removal of an electron from the sulfur lone pair, the highest occupied molecular orbital (HOMO).

Fig. 6 shows a diagrammatic representation of the experimentally determined IPs for some molecules formally containing the sulfenylcarbonyl group, ${ }^{13,36-40}$ which can also be known as $-\mathrm{C}(\mathrm{O}) \mathrm{S}-$ containing compounds. Taking $\mathrm{CH}_{3} \mathrm{OC}(\mathrm{O}) \mathrm{SNCO}^{13}$ as a reference, it can be observed a reduction of the IP values because of the substitution of the NCO by electron-releasing alkyl groups. On the other hand, substitution of the $\mathrm{NCO}$ or SCN groups by more electronegative groups can lead to higher IP values.

The $-\mathrm{C}(\mathrm{O}) \mathrm{S}-$ compounds previously studied had the similar first ionization potential values, which can be assigned as a lone pair formally localized on the sulfur atom (Fig.6). For instance, the ionization potential values of $\mathrm{CH}_{3} \mathrm{OC}(\mathrm{O}) \mathrm{SY}$ series, $\mathrm{ClC}(\mathrm{O}) \mathrm{SY}$ series and $\mathrm{FC}(\mathrm{O}) \mathrm{SY}$ series, the strong inductive effect of $\mathrm{Cl}$ atom or $\mathrm{F}$ atom can raise the ionization energy of sulfur lone pair orbital $n_{\mathrm{S}}$, with respect to the $\mathrm{CH}_{3} \mathrm{OC}(\mathrm{O}) \mathrm{SY}$ molecules. The electronegativity of $\mathrm{F}$ is the strongest, and $\mathrm{CH}_{3}$ is the weakest. So the ionization potentials of FC(O)SY compounds are higher than

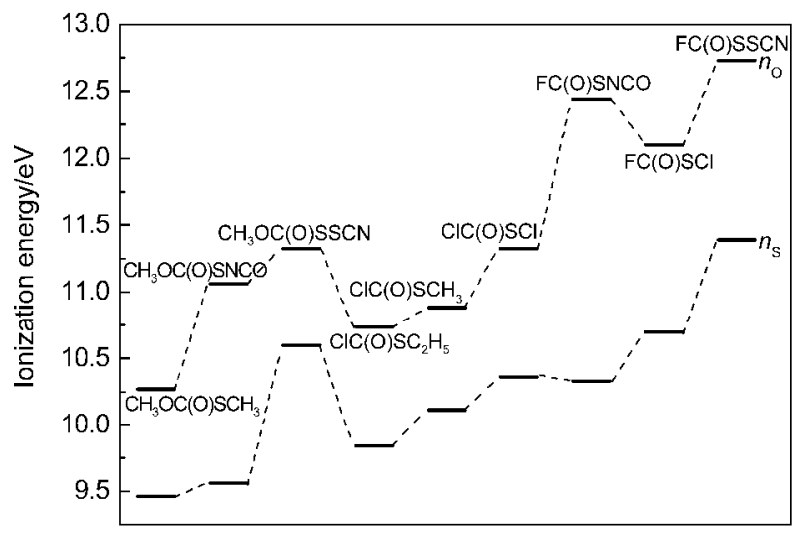

Fig.6 Correlation diagram of the IPs of $-\mathrm{C}(\mathrm{O}) \mathrm{S}-$ containing compounds

The ionization energies of $\mathrm{CH}_{3} \mathrm{OC}(\mathrm{O}) \mathrm{SCH}_{3}, \mathrm{CH}_{3} \mathrm{OC}(\mathrm{O}) \mathrm{SNCO}, \mathrm{CH}_{3} \mathrm{OC}(\mathrm{O}) \mathrm{SSCN}$, $\mathrm{ClC}(\mathrm{O}) \mathrm{SC}_{2} \mathrm{H}_{5}, \mathrm{ClC}(\mathrm{O}) \mathrm{SCl}, \mathrm{FC}(\mathrm{O}) \mathrm{SCl}, \mathrm{FC}(\mathrm{O}) \mathrm{SSCN}$ are taken from Refs. 13, 36-40. 
those of $\mathrm{CH}_{3} \mathrm{C}(\mathrm{O}) \mathrm{SY}$ compounds, and $\mathrm{ClC}(\mathrm{O}) \mathrm{SY}$ compounds are in the middle. Meanwhile, the electronegativity of $-\mathrm{NCO}$ is between $-\mathrm{CH}_{3}$ and $-\mathrm{SCN}$. So the first ionization energy of $\mathrm{FC}(\mathrm{O}) \mathrm{SNCO}$ at $10.33 \mathrm{eV}$ between those of $\mathrm{CH}_{3} \mathrm{OC}(\mathrm{O}) \mathrm{SNCO}^{13}$ and $\mathrm{FC}(\mathrm{O}) \mathrm{SSCN}^{12}$ is very reasonable.

However, this effect must be interpreted in terms of delocalization effects, rather than as inductive effects of the substituents. This stabilization seems to be caused by the planar XC(O)S moiety around the $\mathrm{C}\left(s p^{2}\right)$ and is independent of the nature of $\mathrm{X}$. The first IP values of two model compounds $\mathrm{CH}_{3} \mathrm{OC}(\mathrm{O}) \mathrm{SCH}_{3}{ }^{38}$ and $\mathrm{ClC}(\mathrm{O}) \mathrm{SCH}_{3}{ }^{39}$ are 9.46 and $10.11 \mathrm{eV}$, respectively.

In order to analyze the nature of the cation formed in the first ionization process, further calculations (B3LYP/6-311+ $\mathrm{G}(d, p)$ ) were performed. It demonstrated that the atomic charges were a palpable fraction localized at sulfur atoms, with delocalized all over the molecule (Table 4). Table 3 summarized the optimized structural parameters of the cationic-radical form. The adiabatic potential of $\mathrm{FC}(\mathrm{O}) \mathrm{SNCO}$ is $9.87 \mathrm{eV}$, which was derived from the different energies between the neutral and ground cationic-radical forms at B3LYP/6-311G $(d, p)$ level of theory. Further vibrational calculations were performed for the cationic-radical form, which resulted in shift $\left(128 \mathrm{~cm}^{-1}\right)$ of the wavenumber for $v_{\mathrm{c}=\mathrm{O}}$ toward higher values, as compared to the neutral molecular, while the $v_{\mathrm{C}-\mathrm{s}}$ wavenumber exhibits a shift of $23 \mathrm{~cm}^{-1}$ in the opposite direction. With the interruption of the mesomeric effect and a reinforced bond character in the $\mathrm{C}=\mathrm{O}$ bond and decreasing in the corresponding $\mathrm{S}-\mathrm{C}$ bond, the picture of an electron ionization mainly localized at the $\mathrm{S}$ atom.

The second band of $\mathrm{FC}(\mathrm{O}) \mathrm{SNCO}$ at $12.44 \mathrm{eV}$ in the photoelectron spectrum, which is due to the electrons ionization from the orbital 29a (Fig.5), can be assigned to the oxygen lone pair $n_{0}$ of the carbonyl group with some admixture out-of-plane nonbonding orbital on the NCO moiety. This value is consistent with the IPs of the oxygen lone pair orbitals in the correlative species. The second band of $\mathrm{FC}(\mathrm{O}) \mathrm{SCl}^{35}$ is at $12.1 \mathrm{eV}$ which can be contribute to the removal of an electron from the lone pair electron of oxygen atom of the carbonyl group, and is higher than that of $\mathrm{FC}(\mathrm{O}) \mathrm{SNCO}$ by $0.34 \mathrm{eV}$. The forth IP of $\mathrm{FC}(\mathrm{O}) \mathrm{SSCN}^{12}$ at 12.73 $\mathrm{eV}$ is mainly due to the lone pair electron of oxygen atom. In contrast to $\mathrm{FC}(\mathrm{O}) \mathrm{SCl}$ and $\mathrm{FC}(\mathrm{O}) \mathrm{SSCN}$, the third ionization band of $\mathrm{FC}(\mathrm{O}) \mathrm{SC}(\mathrm{O}) \mathrm{CH}_{3}{ }^{41}$ is at $11.80 \mathrm{eV}\left(n_{\mathrm{O}(\mathrm{FC}(\mathrm{O}))}\right)$. The trend showed a clear dependence on the substituents attached to the sulfur atom. Therefore, in the series of $\mathrm{FC}(\mathrm{O}) \mathrm{SX}\left(\mathrm{X}=\mathrm{NCO}, \mathrm{SCN}, \mathrm{C}(\mathrm{O}) \mathrm{CH}_{3}\right)$ species, the $\mathrm{FC}(\mathrm{O}) \mathrm{SNCO}$ molecule possessed higher stabilization of the oxygen lone pair.

The bands at 13.23 and $13.77 \mathrm{eV}$ can be assigned of ionization electrons on the in-plane lone pair of carbonyl oxygen $\pi_{c o}^{\prime}$ and the in-plane $\pi_{\mathrm{SNCO}}^{\prime}$. The orbit $\pi_{\mathrm{SNCO}}^{\prime}$ consists the the in-plane of isocyanate and in-plane lone pair of sulfur. The fifth band originates from ionizations related to the $\mathrm{FC}(\mathrm{O})$ moiety. Interactions between the $\pi_{\mathrm{C}=\mathrm{O}}$ and $n_{\mathrm{F}}$ localized orbitals become effective in the planar geometry of the $\mathrm{FC}(\mathrm{O})$ moiety. Howere, it is impossible to have this interaction in the in-plane lone-pair orbital. From the above, the band at $14.78 \mathrm{eV}$ may involve $\pi_{\mathrm{C}=\mathrm{O}}$ and $n_{\mathrm{F}}$ orbitals. The related species had the similar ionization potentials of the $\mathrm{C}=\mathrm{O}$ group orbitals, such as $\mathrm{CH}_{3} \mathrm{OC}(\mathrm{O}) \mathrm{SCH}_{3}{ }^{38}(14.18 \mathrm{eV}), \mathrm{FC}(\mathrm{O}) \mathrm{SC}(\mathrm{O}) \mathrm{CH}_{3}{ }^{41}$ $(14.10 \mathrm{eV}), \mathrm{FC}(\mathrm{O}) \mathrm{SCl}^{36}(14.9 \mathrm{eV}), \mathrm{FC}(\mathrm{O}) \mathrm{SSCH}_{3}{ }^{36}(14.8 \mathrm{eV})$ and $\mathrm{FC}(\mathrm{O}) \mathrm{SSCN}^{12}(14.17 \mathrm{eV})$. The $\pi_{\mathrm{C}=\mathrm{O}}$ orbital is destabilized by the electron donating effect and stabilized by the resonance interaction with the fluorine non-bonding orbital.

The sixth band at $15.99 \mathrm{eV}$ is just ascribed to the ionization of the orbital $\sigma$ and $n_{\mathrm{F}}$. The band at $15.36 \mathrm{eV}$ of FCOSSCN is mainly due to the lone pair electron of fluorine atom. The corresponding bands inpropynoyl fluoride and formyl fluoride were at 15.4 and $15.5 \mathrm{eV}^{12}$ respectively, which exhibited remarkably similar shapes. The band at higher ionization region $(>16.00 \mathrm{eV})$ can be attributed to the ionization of $\sigma$ orbital, and can be attributed to the ionization of inner orbital of $\mathrm{FC}(\mathrm{O}) \mathrm{SNCO}$, which may be difficult to assign certainly.

\subsection{Photoelectron mass spectrometry}

The PIMS spectroscopy is depicted in Fig.7. Combining the PES and the theoretical results, the PIMS results can be analyzed. The assignments mainly depended on the mass number of the fragments. It shows six peaks: $\mathrm{SN}^{+}(m / z=46), \mathrm{FC}(\mathrm{O})^{+}(m / z=47)$, $\mathrm{FCOSN}^{+}(m / z=93), \mathrm{C}(\mathrm{O}) \mathrm{SNCO}^{+}(m / z=102), \mathrm{SCNO}^{+}(m / z=74)$ and the parent molecular ion $\mathrm{M}^{+}$, among which the dominant features was the parent molecular ion $\mathrm{M}^{+}$peaks.

The energies of the identified fragments and the adiabatic ionization of $\mathrm{FC}(\mathrm{O}) \mathrm{SNCO}$ were computed, to confirm the level of electronic structure theory which is used in the energetics calculation of dissociation pathways. Table 5 shows the experimentally measured values and the calculated results. The experimental ionization energy data of the $\mathrm{FC}(\mathrm{O}) \mathrm{S}$, SNCO, $\mathrm{C}(\mathrm{O}) \mathrm{SNCO}$, and $\mathrm{FC}(\mathrm{O}) \mathrm{SN}$ radicals are not available. Since the experimental ionization energies are in very good agreement with the calculated ionization energies of the other fragments, the calculated ionization energies for these radicals can be used to estimate the actual values. Theoretical calculation was performed to estimate the energies of the dissociation pathway. These ionization energies are necessary to construct the energy diagrams of different pathways for the ionic dissociation of the parent ion shown in Fig.8.

\subsection{Dissociation of fluorocarbonyl sulfenyl isocyanate}

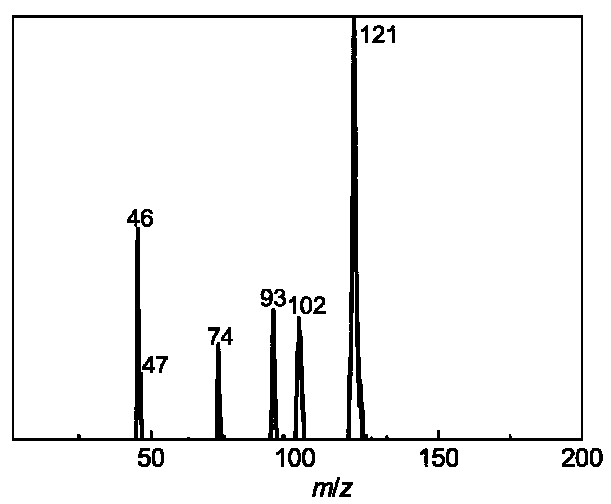

Fig.7 PIMS spectrum of FC(O)SNCO 
Table 5 Calculated and experimental ionization potentials of $\mathrm{FC}(\mathrm{O}) \mathrm{SNCO}$ and its fragments

\begin{tabular}{|c|c|c|c|}
\hline \multirow{2}{*}{ Molecule } & \multirow{2}{*}{ Energy/hartree } & \multicolumn{2}{|c|}{$\mathrm{IP} / \mathrm{eV}$} \\
\hline & & calcd. $^{a}$ & expt. \\
\hline $\mathrm{FC}(\mathrm{O}) \mathrm{SNCO}$ & -779.542399 & 9.87 & $9.85^{\mathrm{b}}$ \\
\hline $\mathrm{FC}(\mathrm{O}) \mathrm{SNCO}^{+}$ & -779.179679 & & \\
\hline $\mathrm{FC}(\mathrm{O}) \bullet$ & -213.161374 & 9.66 & $9.30 \pm 0.10^{42}$ \\
\hline $\mathrm{FC}(\mathrm{O})^{+}$ & -212.806439 & & \\
\hline $\mathrm{FC}(\mathrm{O}) \mathrm{S} \cdot$ & -611.408511 & 11.27 & - \\
\hline $\mathrm{FC}(\mathrm{O}) \mathrm{S}^{+}$ & -610.994317 & & \\
\hline SNCO• & -566.283010 & 10.13 & - \\
\hline $\mathrm{SNCO}^{+}$ & -565.910710 & & \\
\hline $\mathrm{NCO} \bullet$ & -168.044804 & 11.90 & $11.76 \pm 0.01^{43}$ \\
\hline $\mathrm{NCO}^{+}$ & -167.546371 & & \\
\hline $\mathrm{SCO} \cdot$ & -511.590978 & 11.23 & $11.22^{44}$ \\
\hline $\mathrm{SCO}^{+}$ & -511.178217 & & \\
\hline $\mathrm{CO} \bullet$ & -113.344011 & 14.20 & $14.1^{45}$ \\
\hline $\mathrm{CO}^{+}$ & -112.822266 & & \\
\hline $\mathrm{C}(\mathrm{O}) \mathrm{SNCO} \bullet$ & -679.637398 & 8.90 & - \\
\hline $\mathrm{C}(\mathrm{O}) \mathrm{SMCO}^{+}$ & -679.310496 & & \\
\hline $\mathrm{F}^{\bullet}$ & -99.760581 & 21.40 & \\
\hline $\mathrm{F}^{+}$ & -98.974241 & & \\
\hline $\mathrm{FC}(\mathrm{O}) \mathrm{SN} \bullet$ & -666.102722 & 9.62 & - \\
\hline $\mathrm{FC}(\mathrm{O}) \mathrm{SN}^{+}$ & -665.749312 & & \\
\hline $\mathrm{SN} \bullet$ & -452.901060 & 9.15 & $9.85 \pm 0.28^{46}$ \\
\hline $\mathrm{SN}^{+}$ & -452.564669 & & \\
\hline S• & -398.133071 & 10.51 & $10.5 \pm 0.3^{47}$ \\
\hline $\mathrm{S}^{+}$ & -397.746958 & & \\
\hline
\end{tabular}

Besides the studies of the PES and PIMS, the dissociation processes of $\mathrm{FC}(\mathrm{O}) \mathrm{SNCO}$ were also investigated in this work.

The neutral ground state of $\mathrm{FC}(\mathrm{O}) \mathrm{SNCO}$ possesses the $C_{1}$ symmetry with a non-planar conformer $\left(\delta_{\mathrm{CSNC}}=-22.33^{\circ}\right)$. But $\mathrm{FC}(\mathrm{O}) \mathrm{SNCO}^{+}$has an interesting and important feature with $C_{s}$ symmetry, with $\mathrm{F}$ and $\mathrm{SNCO}$ synperiplanar with $\mathrm{C}=\mathrm{O}$. In other word, $\mathrm{FC}(\mathrm{O}) \mathrm{SNCO}^{+}$is a planar conformer $\left(\delta_{\mathrm{CSNC}}=0^{\circ}\right)$. Removing one electron from the HOMO, lone pair of sulfur atom can influence the geometric parameters. The change in bond lengths is obvious: the $r_{\mathrm{Cl}-\mathrm{S}}$ bond elongates to $0.1907 \mathrm{~nm}$. The occupancy of $\mathrm{C} 1-\mathrm{S}$ band also reduces from $1.97 e$ (electron charge) (neutral) to $0.98 e$ (cation). Therefore, these changes in the geometric parameters can strongly influence the removal of the $\sigma_{\mathrm{Cl}-\mathrm{s}}$ bonding electrons. The strongest interaction describing a conjugation (mesomeric effect) between the $\mathrm{lp}_{\pi} \mathrm{S}$ lone pair and the $\pi^{*}(\mathrm{C} 1-\mathrm{O})$ bond $\left[\operatorname{lp}_{\pi} \mathrm{S}(2) \rightarrow \pi^{*}(\mathrm{Cl}-\mathrm{O})\right]$ is disappeared. All these changes can weaken the $\mathrm{C} 1-\mathrm{S}$ band. All these results demonstrate that the parent ion is easy to have a dissociation on the $\mathrm{C} 1-\mathrm{S}$ single bond to form the $\mathrm{FC}(\mathrm{O})^{+} / \mathrm{SNCO} \cdot$ pair or the $\mathrm{SNCO}^{+} / \mathrm{FC}(\mathrm{O})^{\cdot}$ pair.

The possible dissociation pathways of $\mathrm{FC}(\mathrm{O}) \mathrm{SNCO}^{+\bullet}$ are shown in Fig.8. The dissociation of $\mathrm{FC}(\mathrm{O}) \mathrm{SNCO}^{+}$into $\mathrm{FC}(\mathrm{O})^{+} /$ $\mathrm{SNCO} \cdot(2.46 \mathrm{eV})$ and $\mathrm{SNCO}^{+} / \mathrm{FC}(\mathrm{O}) \cdot(2.93 \mathrm{eV})$ are energetically favorable over most ways. However, the dissociation of $\mathrm{FC}(\mathrm{O}) \mathrm{SNCO}^{+} \cdot$ into $\mathrm{FCOSN}^{+} / \mathrm{CO} \cdot(2.35 \mathrm{eV})$ is the easiest channel, which is lower than $\mathrm{FC}(\mathrm{O})^{+} / \mathrm{SNCO} \cdot$ by $0.11 \mathrm{eV}$. The other two dissociation pathways are $\mathrm{SNCO}^{+} / \mathrm{FC}(\mathrm{O}) \cdot(2.93 \mathrm{eV})$ and $\mathrm{C}(\mathrm{O}) \mathrm{SNCO}^{+} / \mathrm{F} \cdot(2.96 \mathrm{eV})$. Through the above four ways, we can obtain $\mathrm{FC}(\mathrm{O}) \mathrm{SN}^{+}, \mathrm{FC}(\mathrm{O})^{+}, \mathrm{SNCO}^{+}$, and $\mathrm{C}(\mathrm{O}) \mathrm{SNCO}^{+}$. Because $\mathrm{SNCO}^{+}$can easily dissociate into $\mathrm{SN}^{+} / \mathrm{CO} \cdot, \mathrm{FC}(\mathrm{O}) \mathrm{SN}^{+}$into $\mathrm{SN}^{+} /$ $\mathrm{FC}(\mathrm{O}) \cdot$, and $\mathrm{F} \cdot / \mathrm{C}(\mathrm{O}) \mathrm{SNCO}^{+}$into $\mathrm{F} \cdot / 2 \mathrm{CO} \cdot / \mathrm{SN}^{+}$, which only need $0.05,0.63$, and $1.57 \mathrm{eV}$, respectively. This is why $\mathrm{SN}^{+}$appeared in photoionization mass spectrum and had the second highest intensity. The energies of the dissociation into $\mathrm{FC}(\mathrm{O})^{+}, \mathrm{SNCO}^{+}$, $\mathrm{FC}(\mathrm{O}) \mathrm{SN}^{+}, \mathrm{C}(\mathrm{O}) \mathrm{SNCO}^{+}$are very nearly, so the intensities of their bands are similar. Thus, the ion intensities observed in the photoionization mass spectrum can be explained by anticipating the dissociation pathways.

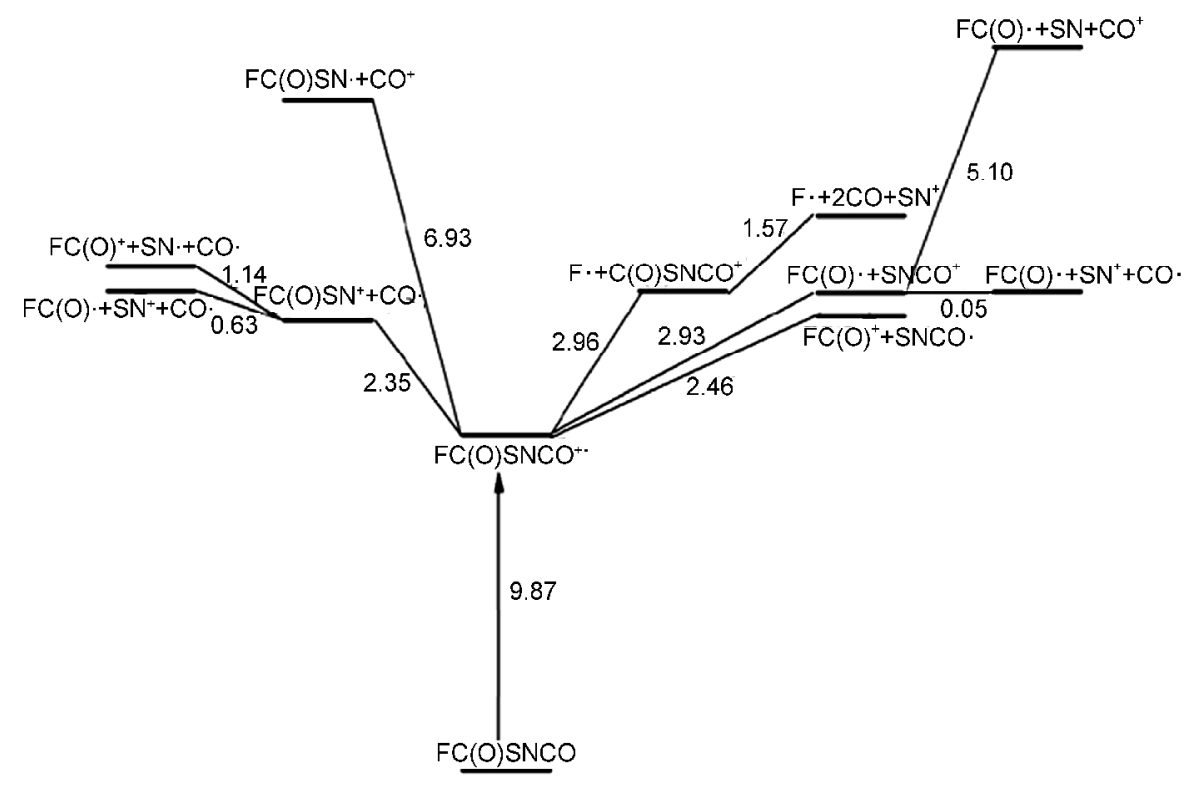

Fig.8 Schematic energy profile (eV) showing ionization and dissociation pathways of $\mathrm{FC}(\mathrm{O}) \mathrm{SNCO}$ calculated at the B3LYP/6-311++G $(d, p)$ level 


\section{Conclusions}

FC(O)SNCO was synthesized by the reaction between AgOCN and $\mathrm{FC}(\mathrm{O}) \mathrm{SCl}$. The structural and electronic properties of $\mathrm{FC}(\mathrm{O}) \mathrm{SNCO}$ were studied by combination of experiment, theoretical studies, and NBO analysis, before characterizing by PES and PIMS. The result showed that the most stable conformer for the title molecule was the syn-syn from with $C_{1}$ symmetry. After ionization, the cationic-radical $\mathrm{FC}(\mathrm{O}) \mathrm{SNCO}^{+}$adopted syn-syn structure with $C_{s}$ symmetry and planar conformer. Combining with OVGF calculation, the PES spectrum was assigned. Because of the geometric change after ionization, the first vertical ionization energy $(10.33 \mathrm{eV})$ was different from the first adiabatic ionization energy $(9.87 \mathrm{eV})$. In the PIMS of FC(O)SNCO, there were six peaks: $\mathrm{SN}^{+}, \mathrm{FC}(\mathrm{O})^{+}, \mathrm{SNCO}^{+}, \mathrm{FC}(\mathrm{O}) \mathrm{SN}^{+}, \mathrm{C}(\mathrm{O}) \mathrm{SNCO}^{+}$, and $\mathrm{FC}(\mathrm{O}) \mathrm{SNCO}^{+}$. According to the calculated bond dissociation energies, the investigations of possible ionization and dissociation processes were presented. Our investigation on the electronic structure of fluorocarbonyl sulfenyl isocyanate may have further implications for the understanding the chemical behavior of $\mathrm{FC}(\mathrm{O}) \mathrm{SNCO}$.

\section{References}

(1) Watson, J. D.; Gann, A.; Baker, T. A.; Levine, M.; Bell, S. P.; Losick, R.; Harrison, S. C. Molecular Biology of the Gene, 7th ed.; CSH Press: New York, 2013; pp 66-67.

(2) Ibarra, C. A.; Chowdhury, P.; Petrich, J. W.; Atkins, W. M. J. Biol. Chem. 2003, 278, 19257. doi: 10.1074/jbc.M301566200

(3) Hass, A.; Reinke, H. Angew. Chem. Int. Edit. 1967, 6, 705.

(4) Della Vedova, C. O.; Varetti, E. L.; Aymonino, P. J. Can. J. Spectrosc. 1983, 28, 107

(5) Della Vedova, C. O.; Cutin, E. H.; Jubert, A. H.; Varetti, E. L.; Aymonino, P. J. Can. J. Spectrosc. 1984, 29, 130.

(6) Mack, H. G.; Oberhammer, H.; Della Vedova, C. O. J. Phys. Chem. 1991, 95, 4238. doi: 10.1021/j100164a014

(7) Romano, R. M.; Della Vedova, C. O.; Boese, R. J. Mol. Struct. 1999, 475, 1. doi: 10.1016/S0022-2860(98)00439-6

(8) Della Vedova, C. O. J. Roman Spectrosc. 1989, 20, 729. doi: 10.1002/jrs.v20:11

(9) Della Vedova, C. O.; Mack, H. G. Inorg. Chem. 1993, 32, 948. doi: $10.1021 / \mathrm{ic} 00058 \mathrm{a} 032$

(10) Della Vedova, C. O.; Hass, A. Z. Anorg. Allg. Chem. 1991, 600, 145.

(11) Della Vedova, C. O. Spectrochim. Acta 1990, 46A, 1073.

(12) Tong, S. R.; Du, L.; Yao, L.; Ge, M. F.; Della Vedova, C. O. Eur. J. Inorg. Chem. 2008, 3987.

(13) Ma, C. P.; Ge, M. F. J. Mol. Struct. 2008, 892, 68. doi: 10.1016/j. molstruc.2008.04.061

(14) Tong, S. R.; Ge, M. F.; Wang, W. G.; Della Vedova, C. O. J. Mol. Struct. 2009, 921, 274. doi: 10.1016/j. molstruc.2009.01.005

(15) Della Vedova, C. O.; Varetti, E. L.; Aymonino, P. J. Can. J. Spectrosc. 1984, 29, 69.
(16) Ulrich, H. Chemistry and Technology of Isocyanates; Wiley: New York, 1996.

(17) Mack, H. G.; Oberhammer, H.; Della Vedova, C. O. J. Mol. Struct. 1992, 265, 359. doi: 10.1016/0022-2860(92)80113-V

(18) Badawi, H. M.; Forner, W.; Abu-Sharkh, B. F.; Oloriegbe, Y. S. J. Mol. Model. 2002, 8, 44. doi: 10.1007/s00894-001-0066-5

(19) Durig, J. R.; Guirgis, G. A.; Krutules, K. A. J. Mol. Struct. 1994, 328, 97. doi: 10.1016/0022-2860(94)08388-6

(20) Gobbato, K. I.; Ulic, S. E.; Della Vedova, C. O.; Mack, H. G.; Oberhammer, H. Chem. Phys. Lett. 1997, 266, 527. doi: 10.1016/S0009-2614(97)00040-7

(21) Ulica, S. E.; Hermannc, A.; Della Vedova, C. O. J. Mol. Struct. 2002, 641, 233.

(22) Ge, M. F.; Wang, J.; Zhu, X. J.; Sun, Z.; Wang, D. X. J. Chem. Phys. 2000, 113, 1866. doi: 10.1063/1.481990

(23) Cao, X. Y.; Wu, W.; Wang, D.; Ge, M. F.; Wang, D. X. Acta Phys. -Chim. Sin. 2000, 16, 491. [曹晓燕, 吴 伟, 王 东, 葛 茂发, 王殿勋. 物理化学学报, 2000, 16, 491.] doi: 10.3866/ PKU.WHXB20000603

(24) Yao, L.; Zeng, X. Q.; Ge, M. F.; Wang, W. G.; Sun, Z.; Du, L.; Wang, D. X. Eur. J. Inorg. Chem. 2006, 2006, 2469.

(25) Erben, M. F.; Della Védova, C. O.; Willner, H.; Trautner, F.; Oberhammer, H.; Boese, R. Inorg. Chem. 2005, 44, 7070.

(26) Erben, M. F.; Romano, R. M.; Della Védova, C. O. J. Phys. Chem. A 2004, 108, 3938. doi: 10.1021/jp038058y

(27) Haas, A.; Reinke, H. Chem. Ber. 1969, 102, 2718.

(28) Du, L.; Yao, L.; Ge, M. F. J. Mol. Struct. 2008, 882, 146. doi: 10.1016/j.molstruc.2007.09.024

(29) Du, L.; Yao, L.; Ge, M. F. J. Phys. Chem. A 2007, 111, 11787. doi: 10.1021/jp075164h

(30) Frisch, M. J.; Trucks, G. W.; Schlegel, H. B.; et al. Gaussian 03, Revision B.03; Gaussian Inc.: Pittsburgh, PA, 2003.

(31) Ramos, L. A.; Ulic, S. E.; Romano, R. M.; Erben, M. F.; Lehmann, C. W.; Bernhardt, E.; Beckers, H.; Willner, H.; Della Vedova, C. O. Inorg. Chem. 2010, 49, 11142. doi: 10.1021/ ic101741e

(32) Ge, M. F.; Ma, C. P.; Xue, W. J. Phys. Chem. A 2009, 113, 3108. doi: $10.1021 / \mathrm{jp} 8110277$

(33) Du, L.; Yao, L.; Zeng, X. Q.; Ge, M. F. J. Phys. Chem. A 2007, 111, 4944. doi: 10.1021/jp070601d

(34) Zeng, X. Q.; Ge, M. F.; Du, L.; Sun, Z.; Wang, D. X. J. Mol. Struct. 2006, 800, 62. doi: 10.1016/j.molstruc.2006.03.080

(35) Deleuze, M. S.; Giuffreda, M. G.; François, J. P. J. Phys. Chem. A 2002, 106, 5626. doi: 10.1021/jp014260u

(36) Erben, M. F.; Della Védova, C. O. Inorg. Chem. 2002, 41, 3740. doi: $10.1021 /$ ic 0200460

(37) Gerones, M.; Erben, M. F.; Romano, R. M.; Della Vedova, C. O.; Yao, L.; Ge, M. F. J. Phys. Chem. A 2008, 112, 2228. doi: $10.1021 /$ jp 7101034

(38) Ma, C. P.; Ge, M. F. J. Mol. Struct. 2008, 891, 221. doi: 10.1016/ j.molstruc.2008.03.030 
(39) Gerones, M.; Erben, M. F.; Ge, M. F.; Cavasso, R. L.; Romano, R. M.; Della Vedova, C. O. J. Phys. Chem. A 2010, 114, 8049. doi: $10.1021 / \mathrm{jp} 102179 \mathrm{w}$

(40) Du, L.; Yao, L.; Ge, M. F. Eur. J. Inorg. Chem. 2007, 2007, 4514.

(41) Tong, S. R.; Ge, M. F.; Wang, W. G.; Della Vedova, C. O. J. Mol. Struct. 2009, 919, 83. doi: 10.1016/j.molstruc. 2008.08.017

(42) Buckley, T. J.; Johnson, R. D.; Huie, R. E.; Zhang, Z.; Kuo, S. C.; Klemm, R. B. J. Phys. Chem. 1995, 99, 4879. doi: 10.1021/ $\mathrm{j} 100014 \mathrm{a} 002$

(43) Dyke, J. M.; Jonathan, N.; Lewis, A. E.; Mills, J. D.; Morris, A. J. Mol. Phys. 1983, 50, 77. doi: 10.1080/00268978300102181

(44) Frost, D. C.; Lee, S. T.; McDowell, C. A. J. Chem. Phys. 1973, 59, 5484. doi: 10.1063/1.1679898

(45) Fock, J. H.; Gurtler, P.; Koch, E. E. Chem. Phys. 1980, 47, 87. doi: 10.1016/0301-0104(80)80023-1

(46) Ohare, P. A. G. J. Chem. Phys. 1970, 52, 2992. doi: 10.1063/ 1.1673428

(47) Breidung, J.; Thiel, W. J. Phys. Chem. A 2006, 110, 157533.

\section{第十八届全国电化学大会第一轮通知}

由中国电化学会主办、哈尔滨工业大学承办、黑龙江大学协办的第十八届全国电化学大会将于 2015年 8月 7-11 日在黑龙 江省哈尔滨市举行, 本届大会主题是“支撑未来能源发展的电化学”。

全国电化学大会是国内规模最大、范围最广的电化学学术盛会和高水平的学术交流平台,每两年举办一次。本届大会围 绕电化学科学和技术发展中的基础、应用和前沿问题, 全面展示中国电化学领域所取得的最新研究进展和成果, 深入探讨电化 学领域所面临的机遇、挑战和未来发展方向, 推动中国电化学学科的发展和进步, 加强科研合作和技术转化, 促进电化学科学 与技术在能源、环境、材料等重要领域的应用。

中国电化学会热诚邀请国内外从事电化学及其相关领域的基础研究与应用开发、仪器研制以及产业界的同仁共聚美丽的 哈尔滨, 交流和展示最新成果。

会议预定时间: 2015 年 8 月 7-11日

会议地点: 哈尔滨工业大学二校区(哈尔滨市南岗区黄河路 73 号)

\section{征文内容}

电化学基础(包括电极过程动力学、谱学电化学、电催化等)

化学电源(包括锂离子电池、下一代储能电池、其他电池及超级电容器、燃料电池等)

环境和有机电化学(包括环境电化学、有机电合成等)

工业电化学和电化学工程(包括电解、金属腐蚀与防护、电沉积和表面处理技术等)

纳米与材料电化学

电分析化学和生物电化学(包括电化学传感器)

光电化学及新型太阳能电池(包括无机、有机光电材料与器件等)

电化学仪器与设备应用技术

\section{联系方式}

通信地址: 哈尔滨工业大学 1247 信箱, 邮编 150001

联系人

投稿事宜: 程新群, 13895755180, chengxinqun@hit.edu.cn

学术事宜: 杜春雨, 0451-86403961, 15846593646, duchunyu@hit.edu.cn

会务事宜:王振波, 18645006176, wangzhenbo@hit.edu.cn

展览事宜: 左朋建, 0451-86403961, 13836182469, zuopengjian@hit.edu.cn

传真: 0451-86418616

本次会议论文采用在线投稿方式, 关于论文格式要求及其他有关会议详情, 请登陆本次大会网站 http://nce.hit.edu.cn。

第十八届全国电化学大会组委会 哈尔滨工业大学化工学院 